\title{
PROVINCIAL NOIES
}

Arthur Ward has sent us particulars of the bard banding trap he uses at Burnham, "right on the bare prairie apart from any bush area." Last. year he banded 51 bircls but this year has only taken 24 as with an abunciance of water in the vicinity the vircs were less attractec to that within the trap. Two robins retaken this year, had bands dated 1940 and 1941 and a Barn Svallow banded in 1941 returned to the same nesting place. His list incluiles Snys Phoebe, Lark Sparrow and Spotted Towhee, species we never,or else rarely see in the north-eastern part of Saskatchewan.

From Wolseley comes the story of a wren, tame enough to perch on the head or hand.s of members of the Gardon family. J. R. Garclen writes: "This past summer we hack wrens nesting at the back of our house. The parent birds would often fly in the porch to catch flies and got so friendly that one day my cauchter, when vatching them feed their young, held out her hand anc the male bird jumper? on it and started to peck it. I too held out my hand and he did the same thin and then I offered him a green caterpillar which he ate from my fingers. He would often perch on my head and peck it or he would sit on a bough about a foot from rny face as though he hac a notion to $\mathrm{s}_{0}$ for my eres. Sometimes he would sin but most often he seemed in a fichting attitude. The female birr could not be presuaded to come near us anc? as soon as the youn; left the nest her mate too would have nothing more to do vith us.

Althou h hunting bic rame near Arborfield last November, Dr. R. if. Rirkby of Prince Albert brou tht back a tiny animal trophy which is now mounted anc. on view in the Provincial Museum.

Accorcing to the docter it happenec? like this: one evenine a suspicious noise was heard coming from the brear? box suspenced from the limb of a tree just outside the cabin door. The irate hunters, suspecting a rat, faildel to capture the intruder in a first attempt but later on that ni ht got it with a well-rimed blow and found to their dismay the visitor was a Flyine Squirrel.

The point of interest to Dr. Kirkby was the nocturnal habit of this animal, as he had previously believed" "that all squirrels went to bed with the light" and he thinks that perhaps some of our readers may he uncler the same impression.

Flying Squirrels are apparently more common than is usually supposed. They are cistinctly nocturnal in habit and are to he founc. throughout the Wooded parts of western Canacla. Quite recently in "Chickadee Notes" in the Tinnipe Free Press, there was an accnunt of a Flying Squirrel which had occupied a hird house for two years at a Manitoba lakeside cottage. The eclitor of this column, $\hat{A}$. G. Lamrence, points out that "this tiny animal has large Iustrous eyes, as becomes a nicht prowler, tiny ears and thick velvety fur in buff-brown tones above and pure white below. Wicie membranes $j n$ in the fore and hind limbs and on these with logs outstretche? the little glicler 'flies' from tree to tree." 